\title{
Influences of the East on Early Christian Iconography
}

\author{
Maria Chumak \\ Pondicherry University, Kalapet, INDIA \\ School of Humanities, Department of Philosophy
}

Received: 19 July 2020 • Accepted: 25 August 2020 • Published Online: 10 October 2020

\begin{abstract}
The Roman imperial cult is traditionally considered to have been the main root to have exerted a major influence on early Christian iconography. Numerous visual and original literary sources illustrate the replacement of the Roman and Greek deities by the characters of the newly born religion - that is, Christianity. After the legalization of Christianity in the Roman Empire, the honor given to the Roman Emperor was naturally shifted to Jesus Christ, in terms of worship. Establishing the capital of a remote province, such as the Eastern part of Tracie, was a strategic political decision. Roman and later Christian practices inevitably embraced the local cults and traditions. Consequently, both Eastern and Western traditions can be traced in the practices of the new religious faith of the Roman Empire. This paper investigates the major Eastern sources which are often underestimated, while they are present in the Paleo-Christian visuals of the first centuries of the Common Era (CE) in the Eastern territories of the Roman Empire. One of these is the Buddhist visual representations of Gandhara art, which was later endorsed by Manichaeism in order to facilitate the rapid propagation of Mani's teaching. One can observe the oscillating movement of Greek visual representations from the East, with Greek sculptors and painters giving an iconic shape to the existing Buddhist tradition and later back to Christianity on Byzantine territory. These representations were later diluted in equal quantity in the style of Byzantine late antiquity and early medieval visuals.
\end{abstract}

Keywords: Byzantine art, Byzantine studies, Early Christianity, Proto-Christian art, practical theology, Orthodox Christianity, comparative religions, Buddhism, Greco-Indian kingdoms, Gandhara art, liturgy and worship, history of religions, Manichaeism, symbolism.

\section{The origins and meaning of Proto-Christian art}

The newly established Christian religion was disseminated over Roman territory in the first few centuries of the first millennium through the words of the semi-legendary apostolic missionaries, finally taking shape by the beginning of the third century and forming its traditions, including iconography.

Using Christian authors as inspiration, the image-makers of late antiquity expressed themselves in the visual or verbal language which was in use around them. In any religion, devotional representation becomes a cross-disciplinary subject of research, due to the multiplicity of interpretations: it can be examined from the point of view of history, art history, philosophy and theology, culture and sociology.

(C) Authors. Terms and conditions of Creative Commons Attribution 4.0 International (CC BY 4.0) apply. Correspondence: Maria Chumak, Pondicherry University, School of Humanities, Department of Philosophy, Kalapet, INDIA. E-mail: mariachumak.res@pondiuni.edu.in. 
Applying the approach of iconographic studies to this period, one can observe that the primary goal of the visuals was the transmission of information - firstly as religious content and secondly in the proliferation of different forms of piety. The main characters were already recognized by the believers through the inscription of scenes according to the images in the Roman catacombs or marble sarcophagus reliefs. They could be represented in different media, such as sculptural figures, high reliefs or icons, with the same stylistic features.

It is undeniable that multiple features which are inseparable from imperial GrecoRoman imagery passed into the Christian iconographic language as words, expressions, and syntactical or metrical constructions of the first centuries, and that Aramaean, Koine Greek and Latin were interpolated into the language of the Christian Church Fathers and early theologians. ${ }^{1}$ This logical postulate deserves our attention because the first Christian images and texts were created to be understood and accepted by their contemporaries. This can be easily verified by the visual comparison of Christian images which follow the rules of late antiquity in the presentation of human figures, their posture, physical type, costume and habitual gestures and attitudes, accessories and architectural details, with those of the East.

Religious art, evoking religious values and beliefs, sooner or later becomes an intimate part of any tradition. Vladimir Lossky and Leonid Uspensky explain in their works that there are three parts in Christian tradition which are not certified by the Scriptures. These traditions are based on the amalgamation of Jewish, Greek and Roman beliefs and practices during the first to third centuries CE. This idea can be equally applied to the domain of the visual. Often based on the scriptural category, depictions should be in a recognizable form in the essence and significance of a spiritual experience by the believers. ${ }^{2}$

\section{Jewish hostility and Greek visuals}

With the expansion of the Roman Empire, different foreign temples and cults were tolerated in Rome, and synagogues were no exception. Later, Christianity was authorized by the same predisposition. These principles were not new in the history of the Mediterranean region.

Greek philosophical definitions were embedded in Christian ideology from the beginning, to such an extent that they could not later be separated. The idea of the "unseen God", which was not innovative for progressive Greek elitist thought of the first millennium, found its

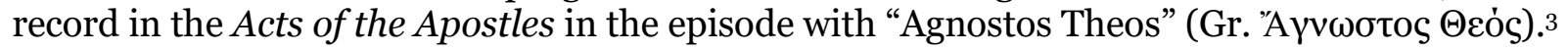

Previously, in the fourth century BCE, due to the military campaigns of Alexander the Great, 4 Greek culture had spread from the Mediterranean Sea as far as the territory of what is now East Pakistan. This movement was historically named "Hellenization", and it reshaped the map of the ancient world. As a result of Hellenization, reciprocal influences can easily be traced in language and in the social and civic organizations of the state.

\footnotetext{
${ }^{1}$ Grabar, André. Christian iconography: A study of its origins, Princeton University Press, Washington DC, 1968, pp. 48-49.

${ }^{2}$ Lossky, Vladimir and Uspensky, Leonid. Смысл икон [The meaning of icons], trans. from French by L. Reshikova, Eskimo, Moscow, 2014, p. 7. (The current translation into English was done by the author of this article.)

3 Acts 17:23.
} 
This cosmopolitan idea of the unity of the territories was perfectly reflected in the Gospels. What distinguished Christianity from previous religious concepts was its modernity and its ability to adapt to the global situation - that is, the new belief proclaimed itself as being for all, with an emphasis on tolerance and humanism: "There is neither Jew nor Greek, there is neither slave nor free, there is no male and female, for you are all one in Christ Jesus. And because you belong to Christ, you are Abraham's descendants, and you are heirs according to God's promise" (Galatians 3:28-29). Jewish hostility towards the Christian images could not sustain the pressure of the rich visual artistic environment around Judea.

Sr. Charles Murray in her fundamental research on early Christian iconography notes that the Decalogue prohibitions should be seen as local and temporary. 5 The presence at the core of the Judaic community of Jewish individuals who were more flexible in matters of religion, prepared to sponsor the representations of animals and human beings and even of the hand of God, was found at the beginning of the first millennium in remote public synagogues - above all, in that of Dura-Europos. All the evidence points to the orthodox and pious nature of the Jewish community who officially sponsored the amazing fresco decoration found there.

The Christian community shared the same location and, unlike the Jews, they could justify the depictions through the incarnation of the Son of God which made it possible for God to be represented. St Paul summarized this idea in his Epistle to the Colossians: "He [Jesus] is the image [icon] of the invisible God" (Colossians 1:15).

The embodiment of the Absolute in Jesus removed the distance as well as the distinctions between God and the human. This link helped to accommodate the aniconism requirement of Judaism and the Greco-Roman visual heritage. St Basil the Great in the fourth century and John of Damascus in the seventh century, in opposition to Tertullian, claimed of holy images that "the honor given to the image reaches back to the original". ${ }^{6}$

The most ancient icons belong to the monastery of Saint Catherine, built on the orders of the Emperor Justinian on Mount Sinai. On stylistic grounds, the earliest tentative date is given to a Virgin and Child between two saints with two very Hellenistic-looking angels. This icon is attributed to the sixth century. The Virgin is depicted in the place of an empress, St Peter in the place of a first consul, and St John (in question) as a second consul. Mary, placed on the throne, wears a formal costume with pearls and precious stones.

The mark of imperial iconography in Christian art is recognizable everywhere in different ways: in the appropriation of themes and subjects, in the borrowings of iconographic details, and in the usage of more remote models for the creation of analogous images. ${ }^{7}$ Christ, sitting solemnly on a throne, wears a crown, makes the sign of benediction, and is surrounded by angels or saints standing along both sides. Chronological dating is the major problem in the study of icons, particularly those of the Byzantine period because of the stylistically strong traditional features, and radiocarbon dating is not efficient due to the constant renovation of the varnish.

\footnotetext{
5 Murray, Charles. "Art and the early church", The Journal of Theological Studies, New Series, Vol. 28, No. 2 (October 1977), pp. 303-345.

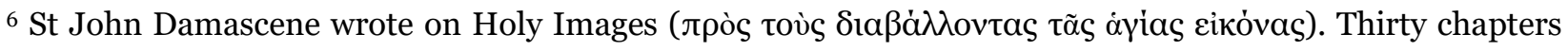
written to Amphilochios deal with the Holy Ghost. - Chap. xviii. Tr. Mary H. Allies, ed. Thomas Baker, London, 1898, Gutenberg Project, Release Date: 9 September 2015 [EBook \#49917].

7 Grabar, André. Christian iconography: A study of its origins, p. 41.
} 


\section{Central Asian Greco-Indian influence}

In addition to the evident influence of the Roman imperial cult on early Christian visuals, as described above, another strong impact that should not be ignored is the oriental source of the Parthian Empire (Persian-Hellenistic), later known as the Bactrian (Indo-Greek) kingdom. To understand its effect on early Christian art, a short historical overview is needed.

The story of this crossroads region begins with the legendary founding of the cities of Taxia (Panjab, Pakistan), Kapisa (Afghanistan) and Purushapura (Pakistan) and goes back to the Mahabharata and the Ramayana. Later, this region was commonly known by the term Gandhara. It became one of the six mahajanapadas (states) of ancient India, referred to in Rigveda (RV 1.126.7) and Atharvavdeda (AV 5.22.14). Conquered by the Achaemenid Empire in the sixth century BCE, this territory became the northwest satrapy, with its capital at Pushkalavati.

By 380 BCE the Persian rule of these regions had weakened. The centralized Gandhara broke into many small kingdoms and finally, in 327 BCE, the Macedonian king Alexander the Great conquered Gandhara along with the Indian satrapies of the Persian Empire. After the death of Alexander, his enormous rapidly established empire crumbled at once and was divided up among his generals, proclaimed as diadochi.

The Roman imperial territory which proliferated mainly to the west from its capital of Rome, never reached the size of Alexander's possessions. In the first centuries CE, the territory of the Roman Empire stretched only around the basin of the Mediterranean Sea, covering the western part of Europe and extending as far as the territory of the northern Celtic tribes. Alexander spread the Greek territory by his invasion of the Eastern part of the known world and that is why the Latin influence on these territories was minimal, known later only by the protracted RomanParthian wars ( $54 \mathrm{BCE}-217 \mathrm{CE}$ ). It should also be noted that Ionian Greeks had been familiar to the Eastern world for centuries before the Macedonian army reached this region. Described by the word "yoana" by the Persians, the precise word "yauna" was mentioned in the Mahabharata, ${ }^{8}$ which described the events of the ninth and eighth centuries BCE. 9

As a result of his education received from Aristotle, Alexander had a more cultural approach than any other conqueror towards the vanquished territories, in a process that would nowadays be termed colonization. The installation of Greek military settlements, and the subsequent founding of cities from plans drawn in the sand, offered huge opportunities to architects, sculptors and painters. The adopted Greek culture built on the Achaemenid heritage of well administered autonomous satraps, providing a fusion of artistic styles, sartorial habits and lifestyles.

Based on the art of the Parthian Empire, three major artistic styles emerged: Gandhara (Afghanistan, Pakistan), Mathura (Uttar Pradesh) and Khalchayan (modern Uzbekistan). This combined region, primarily known as the cradle of Buddhism, had a strategic location for the spread of Buddhism to Central and Eastern Asia. Two examples of the Greek contribution to the proliferation of Buddhism are evident.

King Chandragupta (reign: 321-298 BCE), the founder of the Maurya Empire, may have witnessed Alexander's invasion in his childhood in Taxila; at a later date, when he had become ruler, he married the daughter of Seleucus I Nicator (c. 358-281 BCE), one of Alexander's diadochi. Emperor Ashoka the Great (reign c. 268-232 BCE), the grandson of King Chandragupta, converted to Buddhism and largely contributed to the fast spread of the religion.

\footnotetext{
8 Mahabharata, Adi Parva Chapter 85, v. 34.

9 Kumar, Raj. "Foreign elements in Indian population" in Social and Cultural History of Ancient India, Sumit Enterprises, New Delhi, pp. 341-346.
} 
Another notable example was King Menander I (c. 165/155-130 BCE), known in Indian Pali sources as Milinda. Initially the king of Bactria, he successfully conquered the nearby territory and founded the Indo-Greek Kingdom, known locally as Yavanarajya (Kingdom of Yavanas). The Greek historian Strabo wrote of King Menander: "[he] conquered more tribes than Alexander [the Great]". ${ }^{10}$ Menander and his court ${ }^{11}$ also converted to the Buddhist faith, and he became the patron of the religion. According to the Pali texts, ${ }^{12}$ culture flourished under his rule, and knowledge of Greek philosophy, medicine, law, astronomy, art, music and poetry was harmoniously exchanged with those of Hindu-Buddhist heritage. The basic representation of this time around 100 BCE is aniconic, involving Buddhist symbols such as buddhapada (the foot of Buddha), drahmachakra (the wheel of Drahnma) and stupas. The majority of researchers attribute the phenomenon of the iconic representation of Buddha to the Gandhara artistic tradition under the Kushan Empire during the rule of Kaniska I (128-16o CE), but Benjamin Rowland in his milestone article asserts that "on the basis of the actual fragments and remains found under reliable archaeological conditions, there is every indication that Gandhara schools of sculpture came into existence before the reign of Kaniska."13

It is highly probable that the Greeks were the first to give the prototypes not only to Roman but also to Indian Buddhist sculptors. The chronological dating of the first known GrecoBuddhist statues is uncertain, but the finest and most iconic one, dated first to second century CE, is exhibited in the Tokyo National Museum.

The region of Gandhara, which was the center of Bactrian Zoroastrianism and Hinduism, included minorities of Jews and Christians in its cosmopolitan population. Famed for its local tradition of Greco-Buddhist Art, Gandhara attained its height from the first to the fifth century under the Kushan Empire and flourished at the crossroads of Asia, connecting trade routes and absorbing cultural influences from diverse civilizations. It could be considered as the longestliving independent Greek colony in the world, due to its official usage of the Greek alphabet.

Greco-Buddhist sculpture under the generic name of Gandhara was a stylistic evolution of this hybrid school. Antique sculpture in Northwestern India and Iran appears to have been a considerable part of the stylistic development of the later antique world. The great majority of these co-called Greco-Buddhist sculptures made a sudden and intensive mass appearance at the beginning of the second century CE. This provided Rowland with the reason for his supposition that they were entirely imported from the Roman East, because the best examples stylistically correspond to the works of Syrian artisans of the time of the Roman emperors, Marcus Aurelius and Septimius Severus. ${ }^{14}$ According to the Greco-Roman document "Periplus of the Erythraean Sea", which described the possibilities of navigation and trading opportunities of the different regions, including the Indian subcontinent, this probability cannot be denied; nevertheless, no archaeological evidence has been found. ${ }^{15}$

10 "Menander I", Encyclopædia Britannica, URL: https://www.britannica.com/biography/MenanderIndo-Greek-king. Accessed: 18 March 2020.

${ }_{11}$ "500 yavanas were converted to Buddhism" in N. S. Gupta (ed.), Cultural history of Kapisa and Gandhara, Sundeep Prakashan, Delhi, 1984, pp. 179-213.

${ }^{12}$ The questions of King Milind, trans. T. W. Rhys Davids, Clarendon Press, Oxford, 1890.

13 Rowland, Benjamin., "Gandhara and late Antique Art: The Buddha image", American Journal of Archaeology, Vol. 46, No. 2 (April - June, 1942), pp. 223-236. Stable URL: https://www.jstor.org/stable/499385.

14 Ibid., p. 224.

15 The described region has been very politically unstable for the last century. N. Ahuja, the art historian and professor at Jawaharlal Nehru University in Delhi, stated: "India will look closer at Gandhara art, a product of the intermingling of multiple cultures at the Pakistan-Afghanistan border. Gandhara studies were hard hit after the partition and libraries did not maintain or update their collections. The Taliban bombing 
The role of Gandhara in the evolution of the image of the Buddha has been a point of considerable disagreement among scholars. The Gandhara school drew upon the anthropomorphic traditions of Greco-Roman religions and represented Buddha with a youthful Olympian god-like face, dressed in garments resembling those observed on Roman imperial statues. The Gandhara depiction of the seated Buddha was less successful, later becoming the interpretation of Maitreya. ${ }^{16}$ The naturalistic representation of a garment with easy, free and form-revealing folds is characteristic of the Hellenistic period and also a mark of the carving of drapery in Roman art of the first century CE. Seeing the combination of many different visual inspirations, various scholars who studied the available artefacts at the beginning of the twentieth century proposed different hypotheses, often influenced by their own political and ethnic origin.

The Austrian professor of art history Josef Strzygowski, after combining examples of Palmyrene paintings and sculptures, sarcophagi of Asia Minor, early Christian ivories from Egypt and Coptic textiles, formed his Eurocentric theory and reframed his opinion by introducing the idea of 'Indo-Germanic' elements regarding the Euro-Asian contact zone. Due to his controversial efforts, Germany boasts a prominent collection of Parthian art. His findings should not be ignored, but his conclusions need to be reviewed on account of his sympathy with radical pan-Germanism. ${ }^{17}$

In contrast with Strzygowski, the French art historian Alfred C. Foucher (1865-1952), traditionally named the "Father of Gandhara Studies", privileged the Greek over the Roman origin of this region. He observed: "The Indian mind has taken a part no less essential than has Greek genius in the elaboration of the model of the Monk-God. It is a case where the East and the West could have done nothing without each other." 18 Ananda K. Coomaraswamy (1877-1947) firmly favored the Hindu roots of the first Buddhist depictions of the Gandhara School. The Sri Lankanborn, Coomaraswamy was an outstanding personality; educated in Great Britain, he was a scientist, scholar and art historian, and he provided the American museums with the finest collections of Indian art. He firmly devalued the artistic qualities of the sculptures of the beginning of the Christian era. ${ }^{19}$ His unfavorable opinion towards any western influence on Indian art should be also rightly evaluated regarding the time of the Indian fight for independence and his active support of the movement.

No proper independent cooperative research has been conducted over the mutual influence between Buddhism and early Christianity, using the literary and the visual primary sources. Geographically, the Greco-Bactrian kingdom had a strategic geopolitical and cultural relationship between Europe and Asia.

activity, pillages and rapid urbanization devastated these archaeological sites. After the partition, these objects became Pakistani or Afghani. Pakistan more tolerant of its Buddhist legacy is protecting the sites and open to the collaboration with India and Western Universities." Soumitra Das, "The Buddhas of Pakistan", The Hindu, 14 August 2019. https://www.thehindu.com/entertainment/art/the-buddhas-ofpakistan/article29234209.ece.

${ }_{16}$ Maitreya (Sanskrit - maitrī) which literally means "friendliness", referred to the future Buddha, presently a bodhisattva residing in the Tushita heaven, who will descend to the earth to preach anew the dharma ("law") when the teachings of Gautama Buddha have completely decayed. "Maitreya", Encyclopædia Britannica, URL: https://www.britannica.com/topic/Maitreya-Buddhism. Accessed: 18 March 182020.

${ }_{17}$ Falser, Michael "The Graeco-Buddhist style of Gandhara - a 'Storia ideologica', or: how a discourse makes a global history of art", Journal of Art Historiography, No. 13, December 2015.

${ }^{18}$ Foucher, Alfred Charles. "The Greek origin of the image of the Buddha" in The Beginning of Buddhist Art and Other Essays in Indian and Central-Asian Archaeology, trans. L. A. Thomas and F. W. Thomas, Humphrey Milford, London, 1914, pp. 136-137.

19 Coomaraswamy, Ananda K. "The origin of the Buddha image", The Art Bulletin, Vol. 9, No. 4 (June 1927), pp. 287-329. Stable URL: https://www.jstor.org/stable/3046550. 
The only report by Strzygowski, ${ }^{20}$ criticized for its lack of evidence, tries to connect Early Buddhist and early Christian depictions - for example, the head of Christ framed in a nimbus with Buddhist depictions of Gandhara art. ${ }^{21}$

Foucher, in his essay "The Greek origin of the image of Buddha" cites the same two examples from Strzygowski's article:

This Buddhist school finds itself by its origins in contact with our Christian art. Look at these two statues; the one represents Christ, and the other Buddha. The one was taken from a sarcophagus from Asia Minor, and is to-day to be found in Berlin; the other comes from a ruined temple in Gandhara, and is at present in Lahore. Both, with the pose of the right arm similarly draped in their mantles, are direct descendants of a common ancestor, the beautiful Greek statue of the Lateran Museum, called the Orator, in which we have long recognized a Sophocles. It is not to be doubted that, plastically speaking, they are cousins-german. The one is a Greco-Christian Christ; the other is a Greco-Buddhist Buddha. Both are, by the same right, a legacy left in extremis to the old world by the expiring Greek art. ${ }^{22}$

The problem discussed here is in the possessing of the findings without any particular national and ethnical interest of the scholar, e.g. exclusively Indian or European, but bound up with the Gandhara phenomenon with the general history of religion and art. ${ }^{23}$

It is interesting to observe the close parallels that exist between the Hindu-Buddhist and Christian rituals in the usage of lamps, incense, bells, rosaries, tonsures, formal gestures and liturgical music. These cultic elements probably found their way into the Christian form of worship through Alexandria and Coptic monasticism during the first few centuries of the Christian era ${ }^{24}$ through the time of the flourishing of Buddhism in the region of Gandhara. That non-Abrahamic traditional religious elements survived in Christian practices may be traced back to a remote preBuddhist and non-Aryan Indian antiquity. Iconolatry, rituals, and devotion are profoundly rooted in the popular Indian non-Aryan consciousness consisting of Buddhism, Jainism and Hinduism, and at times they are other than they were in in their initial meaning.

The relationship of the Gandhara visuals with those of Byzantine icons has not so far been investigated in depth. It is possible to present some undeniable visual comparisons to demonstrate the interrelation on the surface which came into early Byzantine art through Syria, Egypt or Armenia or other sources.

(1) Looking closely at the depiction of the characters, one can identify the resemblance in the drapery technique, as discussed by Strzygowski and developed by Foucher. The simplification of the depiction of the classic Greek drapery of the ancient formula into a simplified web, formed of surface-carving loops in a U-shape that was adopted from Gandhara sculpture, became popular in the Middle East. This technique, found in Palmyra and Gandhara, was in all probability exported to Europe. The same representation of the drape in the technique of carving

\footnotetext{
${ }^{20}$ Reinach, Théodore. «Le sarcophage de Sidamara » in Monuments et mémoires de la Fondation Eugène Piot, tome 9, fascicule 2, 190, pp. 189-228.

${ }^{21}$ He mentions the narrow side of a sarcophagus, "Relief of Christ", 3rd/early $5^{\text {th }}$ century. (C) Staatliche Museen zu Berlin, Skulpturensammlung und Museum für Byzantinische Kunst / Andres Kilger; CC NC-BYSA, p. 34 .

${ }^{22}$ Foucher, Alfred. "The Greek origin of the image of Buddha", pp. 135-136.

23 Finot, Louis. "L. de la Vallée Poussin, Indo-Européens et Indo-Iraniens: l'Inde jusque vers 300 av. J.-C.”, Bulletin de l'École française d'Extrême-Orient, Vol. 24, 1924, pp. 601-602.

${ }_{24}$ Garbe, R. Indien und Christentum and H. Berstl, Indo-koptische Kunst, pp. 180, 188, in Jahrbuch as. Kunst, 1924.
} 
is seen in the central tympanum of the royal portal of Chartres Cathedral and in the Basilica of St Mary Magdalene, formerly Vézelay Abbey, in France.

(2) Human body depictions of Buddha in Gandhara and early Christian visuals are similar in the proportion of 1 to 5 ratio of the head to the body in comparison with the standardized Egyptian, Greek and Roman depictions where the head is in 1 to 8 ratio to the body size. A reduced body size and enlarged head is the norm for standing figures in the grave stelae and memorials of Palmyra and Dura figures. ${ }^{25}$

(3) Jesus, commonly depicted in the icons with his fingers folded in the form of the "mudra" 26 position, does not correspond to Roman oratory postures. The most common postures of Jesus in Orthodox icons are prana, prithvi, ardhapataka, shuni and sourya mudras; in Hinduism and Buddhism these mudras convey the symbol of incarnation and the presence of the divine in the performer. ${ }^{27}$ Apart from the Gandhara influence, the only other (weak) explanation of how the yogi tradition of mudras penetrated into Byzantine ground could be through Arab travellers and writers such as the scholar Al-Biruni, ${ }^{28}$ one of the major figures in medieval Islamic thought, who wrote about the yoga sūtras in the tenth century CE.

(4) The depiction of a halo in the shape of a disc around the head of the portrayed, indicating the holiness of the character, became the symbol of the Uncreated Light (Greek:

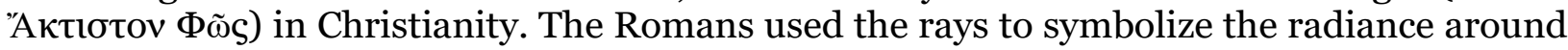
the head of Apollo-Helios to portray him as the sun god. The aureola or mandorla (ovalshaped aureola) present on "Transfiguration" and "Harrowing of Hell" icons are first known in the artistic representations of the Indian subcontinent. The word mandorla, meaning "of the almond" in Italian, could be interrelated with the Sanskrit मण्डल, mandala - literally "circle". It exists in the majority of depictions of Christ in domes and apses in Byzantine art, taking the circular shape. Examples can be seen in the Monastery of Hosios Loukas, Greece, of the eleventh century CE, in the Church of Hosios David in Thessaloniki, and in the dome of the Basilica of San Marco in Venice.

(5) The principle of frontal depiction was first introduced in Parthian imperial art. The figures of humans, heroes and deities looking strictly forward at the spectator and making eye contact were named examples of "Parthian frontality". Unlike Assyrian and Egyptian profile portraiture, similar positions can be seen in archaic Greek and Near East sculptures. "Parthian

25 Gupta N. S. (ed.), Cultural history of Kapisa and Gandhara, Sundeep Prakashan, Delhi, 1984.

${ }_{26}$ Mudra (Sanskrit मुद्रा) is a term with many meanings, "seal", "mark" or "gesture"; in Buddhism and Hinduism, a symbolic gesture of the hands and fingers was used either in ceremonies and dance or in sculpture and painting. Article: Mudra, Encyclopædia Britannica, Date Accessed: March 18, 2020. URL: https://www.britannica.com/topic/mudra.

${ }_{27}$ The example of the overlay of the interpretation of the gesture can be seen in the manual of Dionysius de Fourna (c. 1670-1744), entitled "Mount Athos Painter's Guide": "When you paint the blessing hand, do not join the three fingers together, but only cross the thumb and the fourth finger; so that the upright finger, that is to say the index finger, and the bent middle finger denote the name IC since the upright finger denotes the I, and the curved one which is next to it, the C. ${ }^{27}$ The thumb and the fourth finger, which are crossed, with the little finger beside it, denote the name XC. Since the oblique part of the fourth finger, from where it meets the middle finger, makes the $\mathrm{X}$ sign and the little finger, where it is curved, the $\mathrm{C}$. In this way, the name $\mathrm{XC}$ is shown, and through the divine providence of the creator of all things the fingers of the hand of mankind are formed in such a way, with neither more nor fewer but as many as are sufficient to signify this name." This explanation of the gesture sounds quite weak in its ambiguity.

${ }_{28}$ Abu Rayhan al-Biruni (973 - after 1050), an Iranian scholar, has been variously called the "founder of Indology" for his book Taḥqì mā li-l-hind min maqūlah maqbūlah fí al- 'aql aw mardhūlah ("Verifying all that the Indians recount, the reasonable and the unreasonable"), "Father of comparative religion", "Father of modern geodesy", and the first anthropologist in the time of the Islamic Golden Age. 
frontality" differs considerably from both ancient Eastern and Greek frontality. For both Oriental and Greek art, frontality was an exceptional treatment. With Parthian sculpture, by contrast, the frontal position became the normal treatment of the figures. Later, the same positioning of the characters was visible in the Roman-Syrian sculptures of Palmyra and was adopted into the fabric of Byzantine art. In Greco-Roman art, preference was given to the three-quarter view, distancing the character from the viewer by one hand and providing a more vivid effect of movement to the whole scene. In addition to these characteristics, it is clearly observable that the body texture is more flattened in Oriental examples and made with less precision and voluptuous structure than the facial features and often the hand details.

(6) Hierarchy in the sizing ${ }^{29}$ of the portrayed is commonly used to convey the idea of the magnificence and majesty of the portrayed character. Such a technique was typical for Egyptian, Indian and Iranian methods and was adopted by European art from the time of the Byzantine Empire. In the scenes of the Dormition of the Mother of God and Parinirvana of Buddha in Gandhara art, Buddha and the Virgin Mary are depicted in a similar proportional size in the comparison to the other characters. The position and the compositional cliché may have originated from the iconography of the sleeping Vishnu. ${ }^{30}$

In this realm, iconographical elements in particular have the common characteristics of the Hellenistic, Parthian and Roman crossroads, and they contributed equally to Christian iconography. The traditionally Eastern tradition of proskynesis (prostration) in front of the depiction may indicate a close cultural exchange of the East and West of the Eurasian continent.

\section{Contribution of Manichaeism to the fast spread of Christianity}

A particular movement toward the unification of Eurasian territory took place in the third and fourth centuries CE with the tenets of Mani (c. 216-274 CE) to establish a truly ecumenical and universal religion which was intended to integrate all the partial truths of previous revelations, especially those of Zoroaster, Buddha and Jesus.

Professor Grabar is skeptical concerning whether the visual imagery of Manichaeism helped the wide and fast spread of the teaching to the East and West from Babylon. While the chronological dating of the Dura baptistery belongs to $200 \mathrm{CE}$, it is clear that the earliest Manichean images could not have been produced earlier than 240 CE. Nevertheless Mani, considering himself to be the last prophet, judged the imagery to be capable of expressing ideas and assisting the propagation of the preaching, the same objectives regarding the visuals in Christianity came to the minds of the Early Church Fathers only after the fifth century CE.

Mani showed to his spectators, situated in the large territory from Europe and North Africa to the Chinese Empire, images of God and the depiction of the Last Judgement where the just are rewarded and the evil damned. It is interesting to consider that the second occurrence of a mission which sought to impress potential converts through the spectacle of the Last Judgement, inspired by a mystic's vision, concerns St Augustine of Canterbury's Christian mission to England four centuries later. Mani's positive attitude toward the visual arts helped to prepare the ground and assisted the spread of Christianity as a new religion by

29 This technique consists of the depicturing the more important character in bigger size then the others.

30 Buddha is considered by devotees to be the ninth avatar of Lord Vishnu. 
the syncretism of the previous faith ${ }^{31}$ endorsing this ambitious art, which was as unfamiliar to the Christian virtue of humility in the beginning.

\section{Acknowledgements}

This research did not receive any specific grant from funding agencies in the public commercial, or not-for-profit sectors.

The author declares no competing interests.

\section{References}

Coomaraswamy, A. K. (1927). The origin of the Buddha image. The Art Bulletin, 9(4), 287-329. Stable URL: https://www.jstor.org/stable/3046550.

Damascene, John (n.d.). Apologia of St. John Damascene against those who decry Holy Images, Grand Rapids, MI: Christian Classics Ethereal Library Print Basis: London: Thomas Baker Part, par. 16, URL: http://www.ccel.org/ccel/damascus/icons.html.

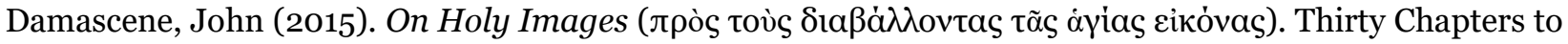
Amphilochios, on the Holy Ghost. - Chap. xviii. Tr. Mary H. Allies, ed. Thomas Baker, London, 1898, Gutenberg Project, Release Date: 9 September 2015, [EBookn\#49917].

Falser, M. (2015). The Graeco-Buddhist style of Gandhara - a 'Storia ideologica', or: how a discourse makes a global history of art. Journal of Art Historiography, 13.

Finot, L. (1924). L. de la Vallée Poussin, Indo-Européens et Indo-Iraniens: l'Inde jusque vers 300 av. J.-C.. Bulletin de l'École française d'Extrême-Orient, 24, 601-602.

Foucher, A. (1914). The Greek origin of the image of the Buddha. In The beginning of Buddhist art and other essays in Indian and Central-Asian archaeology, trans. L. A. Thomas and F. W. Thomas. London: Humphrey Milford.

Grabar, A. (1968). Christian iconography: A study of its origins. Washington DC: Princeton University Press.

Gupta N. S. (Ed.) (1984). Cultural history of Kapisa and Gandhara. Delhi: Sundeep Prakashan.

Kitzinger, E. (1954). The cult of images in the age before Iconoclasm. Dumbarton Oaks Papers, 8, 83-150. URL: https://www.jstor.org/stable/1291064.

Kumar, R. (2007). Social and cultural history of ancient India population. New Delhi: Summit Enterprises.

Лосский В. Н., и Успенский Л. А. (2014). Смысл икон [The meaning of icons]; пер. с фр. В. А. Рещиковой, Л. А. Успенской. Православный Свято-Тихоновский гуманитарный университет: Эксмо, Москва.

Miravalle, M. I. (2006). Introduction to Mary: The heart of Marian doctrine and devotion. Queenship Publishing, S.T.D.

\footnotetext{
31 "Manichæism", New Advent Catholic Encyclopedia. Accessed: 27 March 2020. URL:

http://www.newadvent.org/utility/search.htm?safe=active\&cx=000299817191393086628\%3Aifmbhlr-

8xo\&q=MANICHAEISM\&sa=Search\&cof=FORID\%3Aq.
} 
Murray, C. (1982). Early Christian art and archaeology, Religion, 12, 167-173.

Reinach, T. (1903). Le sarcophage de Sidamara. Monuments et mémoires de la Fondation Eugène Piot, 9(2).

Rhys Davids, T. W. (trans.) (1890). The questions of King Milinda. Oxford: Clarendon Press.

Rowland Jr., B. (1942). Gandhara and Late Antique Art: The Buddha Image. American Journal of Archaeology, 46(2), 223-236. URL: https://www.jstor.org/stable/499385.

Sebastiani, Breno Battistin (2019). Droysen's concept of Hellenism between philology and history. Aitia, 5 . Accessed on 23 October 2019. URL: http://journals.openedition.org/aitia/1336; https://doi.org/10.4000/aitia.1336

Tertullian (2016). Five books against Marcion, Chapter 22, 22:1-13, Ante-Nicene Fathers, Vol. 3, New Apostolic Bible, edited by Covenant.org,.

Трубецкой, Кн. Евгений (1965). Три очерка о русской иконе. Умозрение в красках, два мира в древнерусской иконописи [Three essays on the Russian icon. Speculation in paints, two worlds in ancient Russian icon painting]. Paris, YMCA- Press.

Vatican Council II (2014). Lumen Gentium (Dogmatic constitution of the church), Austin Flannery, Liturgical Press, USA, Collegeville, No. 66.

\section{List of figures}

Fig.1. (Left) Detail of the sculptures from the "House of Cleopatra and Dioscorides", Greece, c. $2^{\text {nd }}$ century BCE. GNU Free Documentation License

Fig. 1. (Right) Buddha, Afghanistan, site of Hadda, Tapa-Kalan monastery, $3^{\text {rd }}-4^{\text {th }}$ century CE, Los Angeles County Museum of Art. Photos of Francesco Bini for public domain

Fig. 2. (Right) Buddha Shakyamuni, Gandhara art, $2^{\text {nd }}-3^{\text {rd }}$ century CE, Pakistan, Gray schist, $120.65 \mathrm{~cm} x$ 40.64 x 49.53cm, Los Angeles County Museum of Art. Photos of Francesco Bini for public domain

Fig. 2. (Left) The Royal Portals of Chartres, France 1145-55. Personal Archives

Fig. 3. (Left) Jesus and Minas, $6^{\text {th }}$ century, $57 \times 57 \mathrm{~cm}$, Bawit in Middle Egypt, Louvre, Paris. Personal Archives

Fig. 3. (Right) Palmyrene Funerary Relief Depicting a Brother and Sister, h. 79 cm, Palmira, Syria 114 AD, State Hermitage museum, St. Petersburg, Russia. Personal Archives

Fig. 4. (Upper) Decoration of the vestibule, site of Hadda, Monastery of Bagh-Gai, $3^{\text {rd }}-4^{\text {th }}$ century CE, Afghanistan, Musée Guimet, Paris. Photos of Francesco Bini for public domain

Fig. 4. (Down) Relief of a sarcophagus withe the depiction of Christ", $3^{\text {rd }}-$ early $5^{\text {th }}$ century. Collection of Strzygowski Staatliche J. Museen zu Berlin, Skulpturensammlung und Museum für Byzantinische Kunst, Berlin. Personal Archives

Fig. 5. (Left) 18th century Tibetan Pattern Book of Proportions, The concept of the 'ideal image' of the Bodhisattva figures was formed the $4^{\text {th }}$ to $6^{\text {th }}$ century CE. Ink drawing book, produced in Nepal or Tibet, $\mathrm{N}$ 930002, verso page 3, from 36 pages, The Getty Research Institute, Los Angeles. Open access photo

Fig. 5. (Right) Christ Pantocrator and Emperor Leo VI, Detail of the mosaic of Emperor Door, $9^{\text {th }}$ century CE, Hagia Sophia, Istanbul, Turkey. Personal Archives 
Fig. 6: (Left) (Maitreya, Gandhara, $58.42 \mathrm{~cm} \times 39.37 \mathrm{~cm}$, c. $2^{\text {nd }}$ century, Provenance: Loriyan Tangai, Swat Valley, N.W.F.P., Pakistan, Indian Museum of Kolkata. Personal Archives

Fig. 6. (Right) The great miracle of Sravasti or the double miracle of water and fire (The Buddha at the Great Miracle.). Gandhara. Afghanistan, Kapisa, Paitava monastery, $3^{\text {rd }}$ century CE, schist with traces of gilding, h. $81 \mathrm{~cm}$. Musée Guimet. Personal Archives
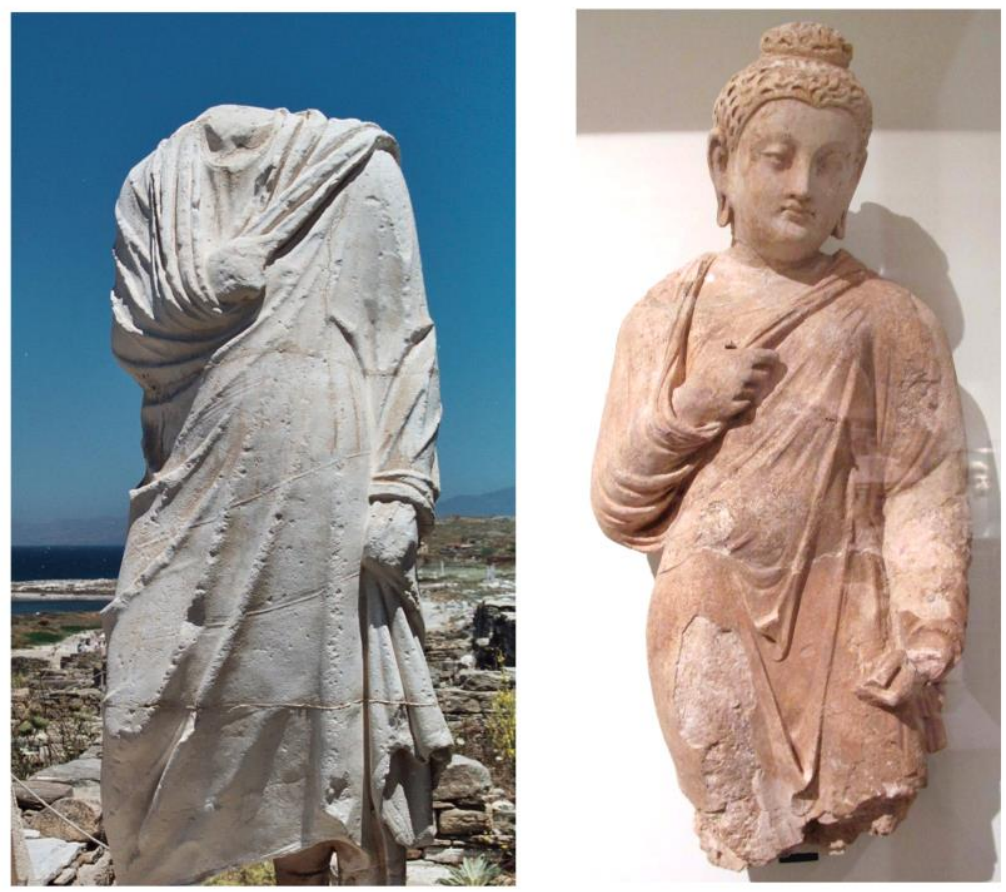

Figure 1
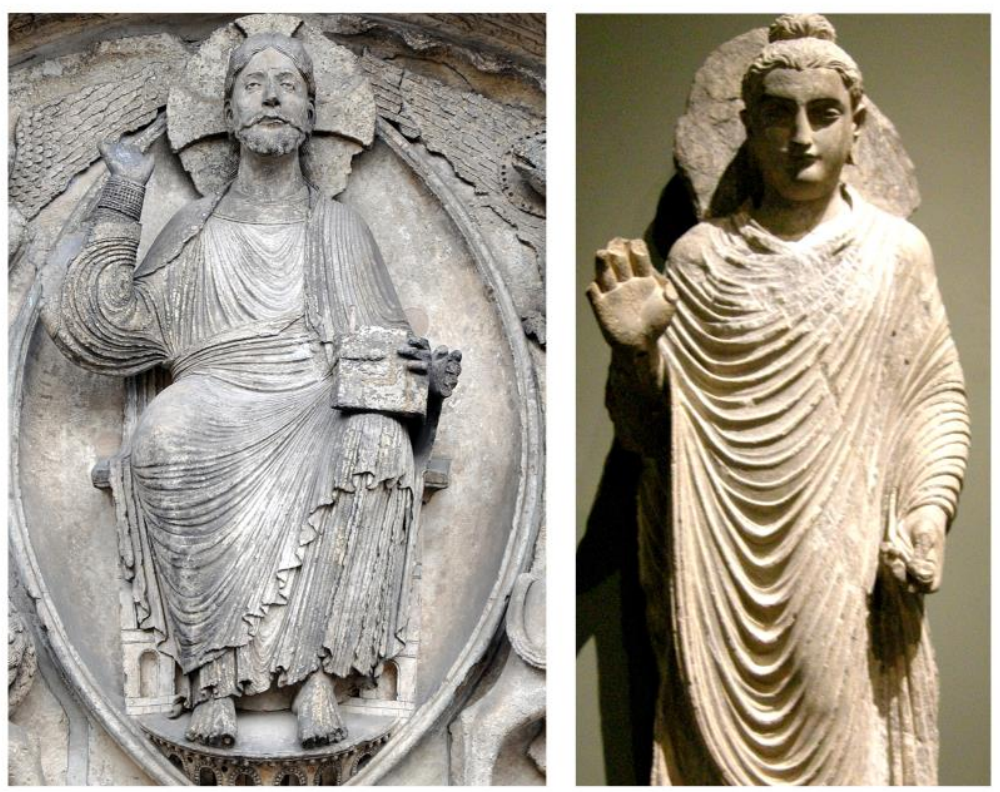

Figure 2 

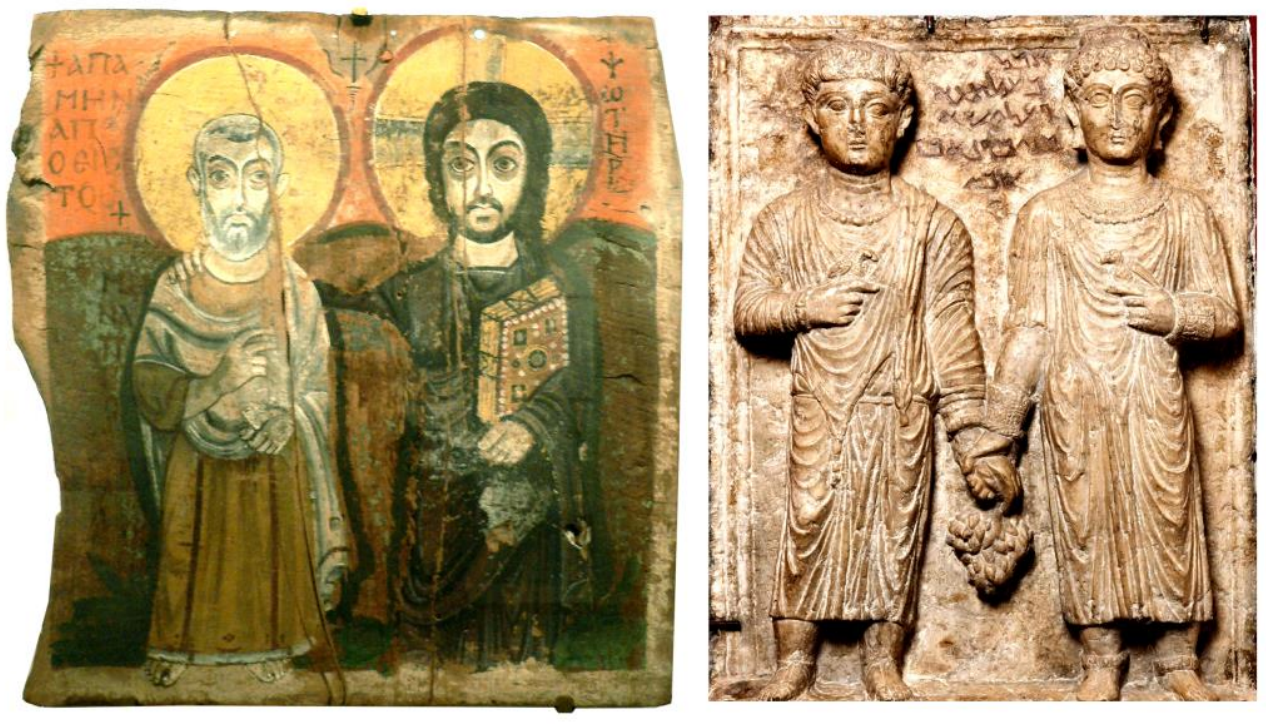

Figure 3
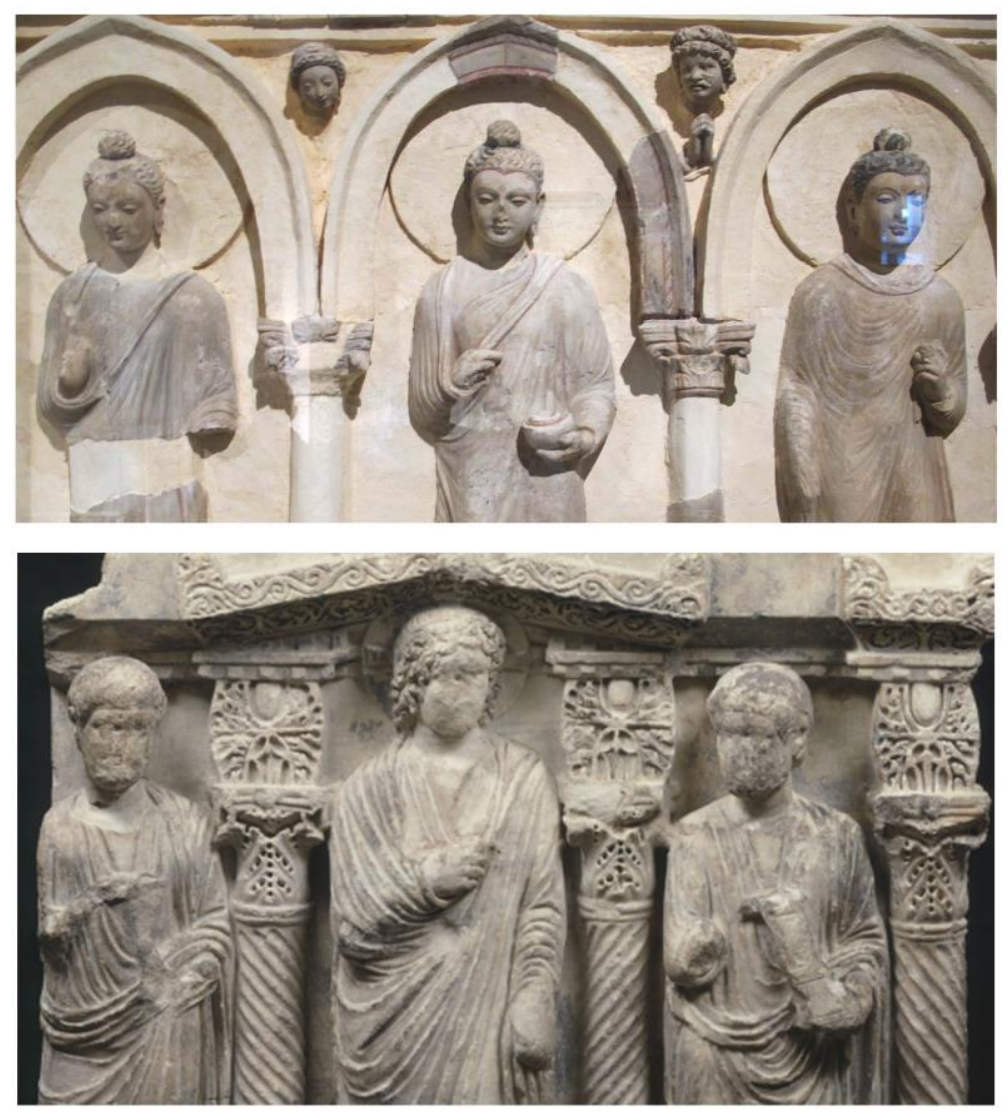

Figure 4 

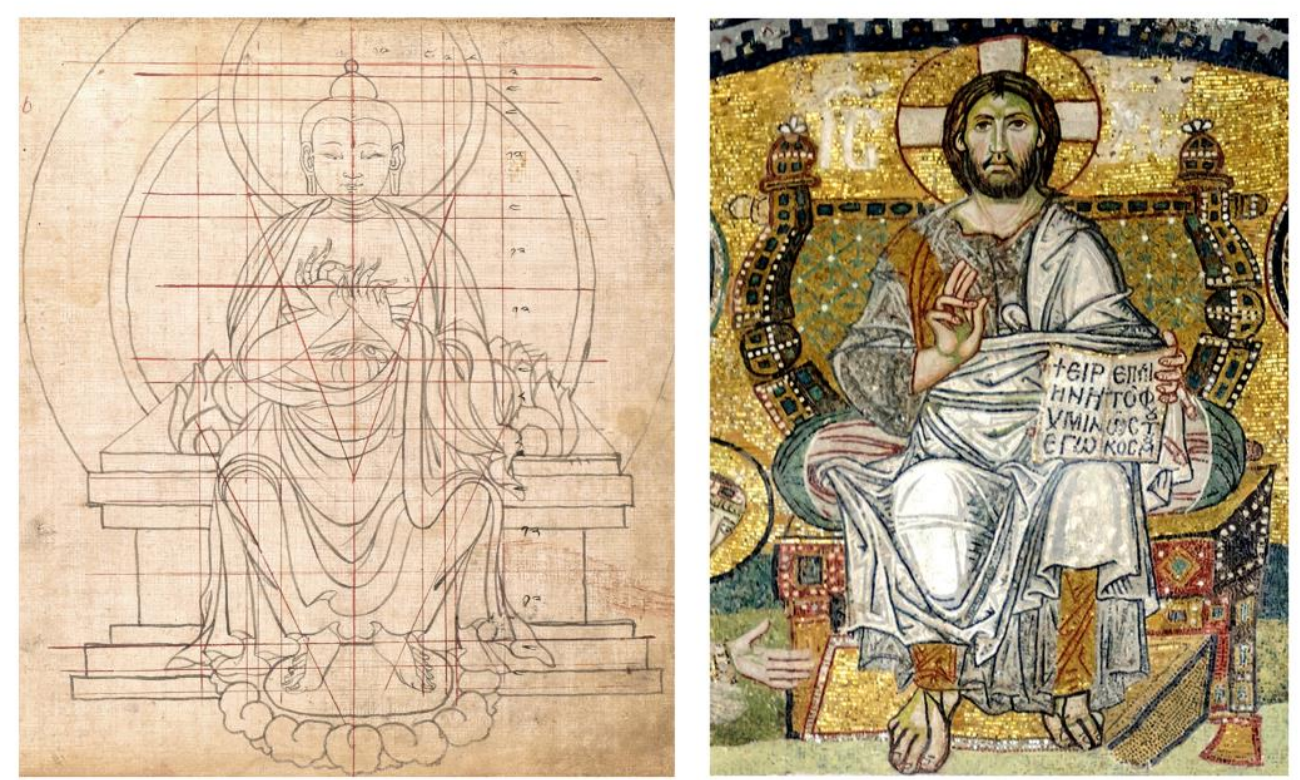

Figure 5
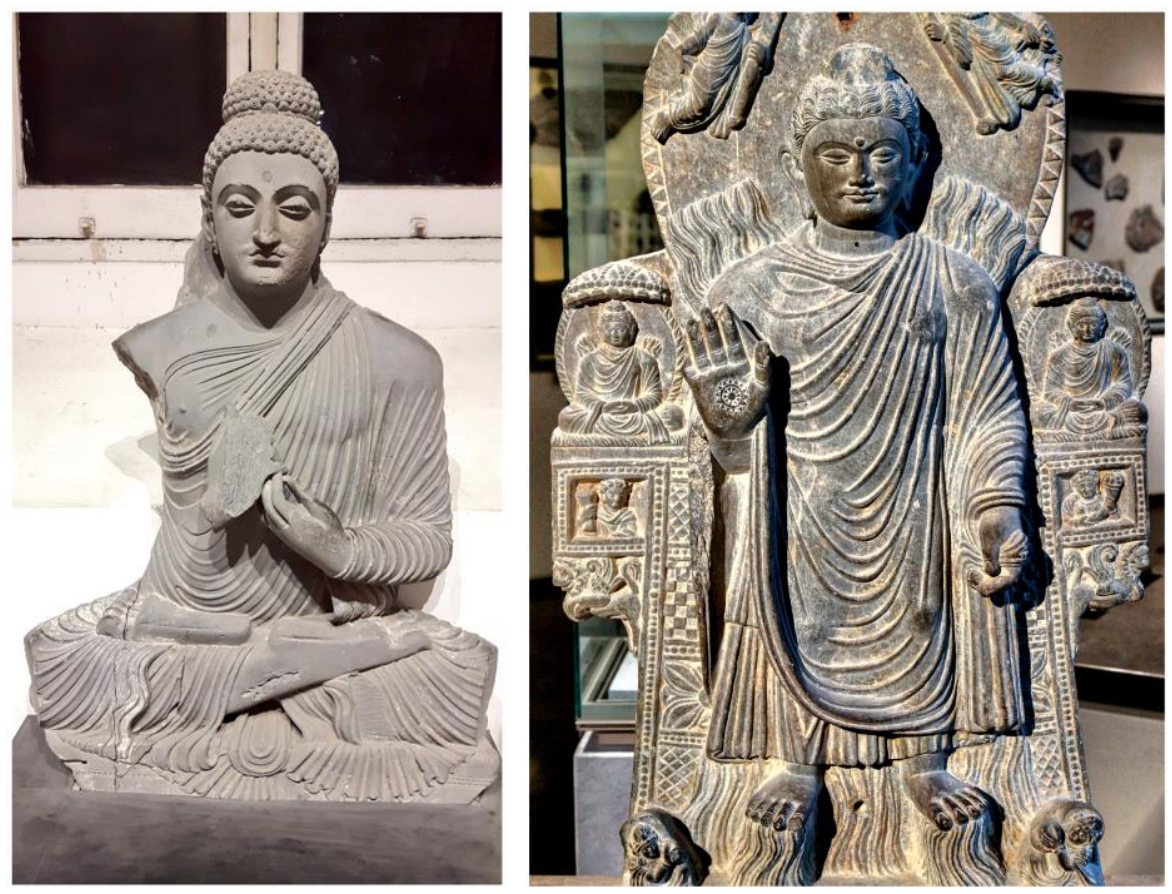

Figure 6

C O A S 